\title{
Old and rare complication of dermatomyositis: calcinosis cutis
}

\author{
Vasco Oliveira Neves, Vera Sarmento, Ana Bernardo, Silvia Lourenço
}

Medicina Interna 2, Hospital do Espirito Santo EPE, Evora, Portugal

Correspondence to Dr Vasco Oliveira Neves: vascoandreneves@gmail.com

Accepted 11 February 2020

\section{DESCRIPTION}

A 68-year-old Caucasian woman complaining of dyspnea was admitted for pneumonia. Her past medical history was significant for dermatomyositis diagnosed 32 years earlier, for which she was treated with prednisolone which was tapered down after 10 years. The diagnosis was supported by skin biopsy and electromyography.

Following admission, she complained of painful skin lesions over the buttocks, thighs and iliac crests (figure 1). These lesions developed after discontinuing glucocorticoid therapy, 15 years prior to presentation. In the last 7 years, the patient reported spontaneous improvement following periods of transepidermal elimination of calcium phosphate salts ${ }^{1}$ (figure 1A).

On physical examination, hard-to-touch whitish lesions were found in the above-mentioned regions, with mild inflammatory changes but no exudation (figure 1B). Radiography of pelvis and upper thighs revealed extensive calcification (figure 2). Laboratory tests showed normal serum levels of parathyroid hormone, calcium, phosphate, creatine kinase and creatinine. The constellation of clinical history and objective findings allowed the diagnosis of dystrophic calcinosis cutis, a rare complication of dermatomyositis. ${ }^{2}$

Calcinosis cutis was described by Virchow as an abnormal deposition of calcium phosphate. ${ }^{3}$ Regarding the aetiology of calcium deposition, it can be divided into four subtypes: dystrophic, metastatic, idiopathic and iatrogenic. Possible causes of metastatic calcinosis include primary and secondary hyperparathyroidism, paraneoplastic hypercalcemia, chronic renal failure and calciphylaxis. The normal serum levels of parathyroid hormone, calcium phosphate and renal function, together with no signs of active cancer, ruled out these causes. There was no history of exposure to hypercalcemic treatments to support the iatrogenic form of the disease, and the location of the lesions was not suggestive of gouty tophi. Therefore, considering the history of dermatomyositis, the diagnosis of the dystrophic form of the disease was made.

Dystrophic calcinosis cutis is the most common form of calcinosis cutis. Most cases occur in association with autoimmune connective tissue diseases, mainly systemic sclerosis and dermatomyositis. ${ }^{2}$ Although this condition is more frequent in juvenile dermatomyositis, it can also occur in adults. ${ }^{2}$ Its underlying mechanisms are not fully understood but these lesions, which are frequently painful and prone to infections,
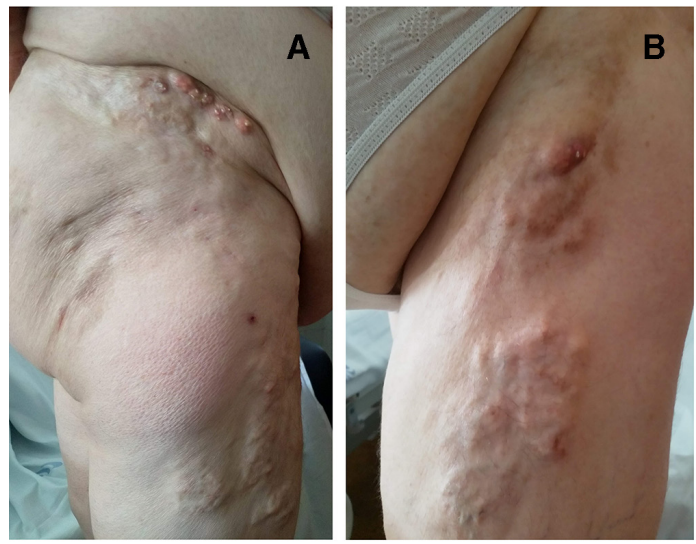

Figure 1 Transepidermal elimination of calcium on the right iliac crest (A). Lateral view of the thigh showing extensive subcutaneous calcification (B).

can improve spontaneously by means of transepidermal elimination of calcium. There is no clearly documented effective treatment but some oral therapies have been used with variable results (diltiazem, colchicine and minocycline). ${ }^{4}$ The main goal of treatment is to relieve symptoms and minimise functional impairment. Surgical removal of calcinosis can be used for discrete symptomatic areas.

This patient presented with a biphasic evolution of the disease, with the last 7 years showing

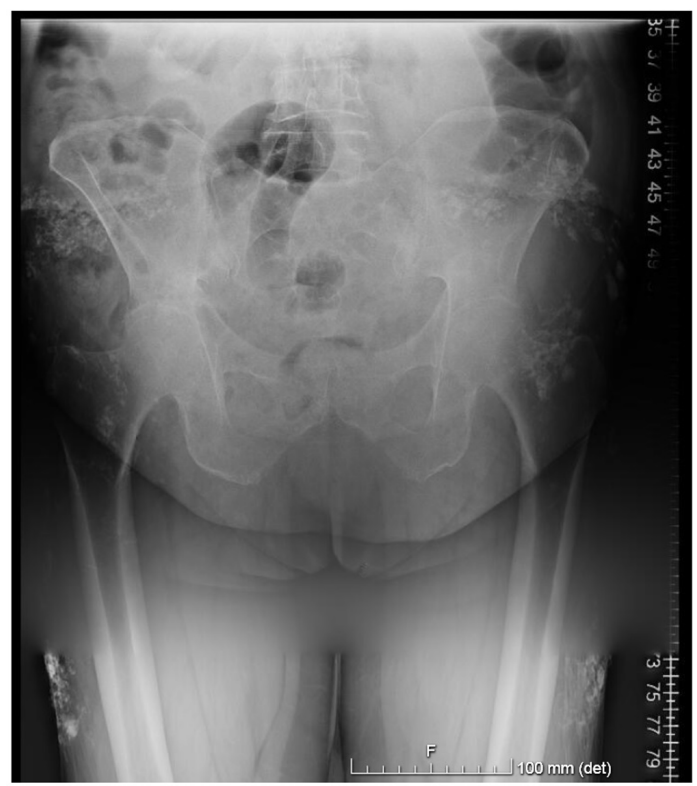

Figure 2 An image of a radiograph of the pelvis and upper thigh showing extensive calcification. 
a spontaneous reduction of calcinosis lesions without any complications.

\section{Learning points}

- Calcinosis cutis is a rare complication of dermatomyositis that can be seen in adult patients.

- Treatment is of little effect but diltiazem, colchicine and minocycline can help to relieve the symptoms.

- Transepidermal elimination of calcium is sometimes reported in calcinosis cutis and can be a way of eliminating calcium.

Contributors All authors contributed significantly to the submitted manuscript. VON wrote the manuscript. VON, VS and AB observed the patient and acquired the data. All authors critically reviewed and approved the manuscript.
Funding The authors have not declared a specific grant for this research from any funding agency in the public, commercial or not-for-profit sectors.

Competing interests None declared.

Patient consent for publication Obtained.

Provenance and peer review Not commissioned; externally peer reviewed.

\section{REFERENCES}

1 Chun SI, Ahn SK. An unusual case of Transepidermal elimination of calcinosis cutis. Ann Dermatol 1989;1:80-2. English.

2 Reiter N, El-Shabrawi L, Leinweber B, et al. Calcinosis cutis: Part I. diagnostic pathway. J Am Acad Dermatol 2011:65:1.

3 Walsh JS, Fairley JA. Calcifying disorders of the skin. J Am Acad Dermatol 1995;33:693-706.

4 Shinjo SK, Souza FHCde. Update on the treatment of calcinosis in dermatomyositis. Rev Bras Reumatol 2013;53:211-4.

Copyright 2020 BMJ Publishing Group. All rights reserved. For permission to reuse any of this content visit

https://www.bmj.com/company/products-services/rights-and-licensing/permissions/

BMJ Case Report Fellows may re-use this article for personal use and teaching without any further permission.

Become a Fellow of BMJ Case Reports today and you can:

- Submit as many cases as you like

- Enjoy fast sympathetic peer review and rapid publication of accepted articles

- Access all the published articles

Re-use any of the published material for personal use and teaching without further permission

Customer Service

If you have any further queries about your subscription, please contact our customer services team on +44 (0) 2071111105 or via email at support@bmj.com.

Visit casereports.bmj.com for more articles like this and to become a Fellow 